\title{
Use of plants and animals by the riverine population from Rio Vermelho Community, central western Brazil
}

O uso das plantas e animais pela população ribeirinha da comunidade Rio Vermelho, centro-oeste brasileiro

\section{L'utilisation de plantes et d'animaux par la population riveraine du Rio Vermelho} communautaire, dans le centre ouest du Brésil

El uso de plantas y animales por la población local de la comunidad de Rio Vermelho, en el centro-oeste de Brasil

\section{Lohan Claudio Abreu Valadares* \\ Maria Corette Pasa**}

Recebido em 12/7/2011; revisado e aprovado em 15/10/2011; aceito em 29/4/2012

\begin{abstract}
This study approached Rio Vermelho community, in the state of Mato Grosso. This type of community is important for supplying the cities with fruits, vegetables and products made from animal's extract. Data obtained shows natural resources are more related to a source of income than self-consumption and the perception of nature in a sense of awe and beauty, not considering important organisms that indirectly benefits or harms their crops and breeding.
\end{abstract}

Key words: Ethnobiology. Riverine Population. Conservation.

Resumo: Este estudo abordou a comunidade Rio Vermelho, no estado de Mato Grosso. Este tipo de comunidade é importante por abastecer cidades com frutas, vegetais e produtos feitos com extratos animais. Resultados obtidos mostram que os recursos naturais utilizados estão mais relacionados à fonte de renda do que ao consumo próprio e que a percepção da natureza está em um sentido de admiração e beleza, não considerando importantes organismos que indiretamente afetam suas plantações ou criações.

Palavras-chave: Etnobiologia. População Ribeirinha. Conservação.

Résumé: Cette étude approché Rio Vermelho communauté, dans l'état du Mato Grosso. Cette communauté est important pour alimenter la ville avec des fruits, légumes et autres produits. Les données obtenues montrent les ressources naturelles sont liées à une source de revenus que l'auto-consommation et la perception de la nature dans un sentiment de crainte et de la beauté, ne tenant pas compte des organismes importants qui profite indirectement ou nuit à leurs cultures et l'élevag.

Mots-clés: Ethnobiologie. Bord de l'eau de la population. Conservation.

Resumen: Este estudio se dirigió a la comunidad de Río Vermlho en Mato Grosso. Este tipo de comunidad es importante para el suministro de frutas, verduras y especias a base de productos de origen animal. Los datos obtenidos muestran que los recursos naturales están relacionados con la fuente de ingresos de su propio consumo y que la percepción de la naturaleza es en un sentido de maravilla y la belleza, sin considerar los daños o beneficios indirectos importantes en su análisis.

Palabras clave: Etnobiología. Población de la orilla del río. Conservación.

\section{Introduction}

Inhabitants of communities with traditional farming systems usually keep a vast knowledge about cultivated plants and animals, and it is also notable the role played by these populations in the exploration of natural resources, both in a sustainable manner or as impactful on the environment (VALADARES; PASA, 2010). Studies that focus on this type of interaction provide greater insight into anthropological knowing and bring environmentally sustainable solutions (SANTOS; ANTONINI, 2008).

Concerning the interaction between plants and humans, Clement (1990) comment there are about 3000 species of plants used by humans as sustenance, but they are also used in medicinal and magical purposes. This interaction, through the evolution of human societies, has provided empirical basis for sciences as Botany, Chemistry and Medicine.

In a review paper of Ethnozoology, Alves and Souto (2011) present that ethnozoology

\footnotetext{
* Departamento de Biologia, Universidade Federal de Mato Grosso (UFMT), Rondonópolis. E-mail: valadareslohan@ gmail.com

** PhD. Professora do Departamento de Biologia, Universidade Federal de Mato Grosso (UFMT), Rondonópolis. E-mail: pasamc@brturbo.com.br
} 
experienced significant advances in recent years in Brazil. The rich fauna and diversity found, with many species of animals used for a wide diversity of purposes presents an excellent backdrop for examining the relationship between humans and other animals.

The study of Ethnoecology has enabled us to understand the process and the cycle cultural information and apply them to develop scientific methods for sustainable human development, so, this paper shows the relationship of inhabitants from Rio Vermelho Community with their plants and animals, and also other organisms that keep a relationship with their crops, as ants.

\section{Materials and methods}

The area is inserted in Cerrado biome, nearby Rio Vermelho river and Jurigue stream $\left(16^{\circ} 30^{\prime} 35.66^{\prime \prime} \mathrm{S}, 54^{\circ} 36^{\prime} 24.80\right)$. The climate is the tropical continental hot humid and dry (SETTE; TARIFFA, 2001). Jurique stream flows on Rio Vermelho river, and this one flows on São Lourenço river, then reaching the south side of Poconé's Pantanal. These watercourses nearby the community are important to the region sustenance due to fishery and agroecology systems along its banks.

Asdescribed by Valadares and Pasa (2010), Rio Vermelho community is characterized by implantation of agroecosystems with 20 occupied farmsteads from a total of 48 , extending from the bank of Jurigue stream to a highway toward Rondonópolis city. It is observed impacts of human activities, mainly agricultural practices, and regeneration of vegetation together with remnants of native forest in unoccupied lots. From 20 farmsteads, we only visited seven. Most of property owners do not live in the community and only use the land for leisure at weekends, and we restricted our research only to people in constant contact with the region.

Data shown in this study were collected between may/2010 to july/2011. First, we applied a pre-test aiming to promote a socioeconomic data and cultural survey of the local population, then, we used semistructured questionnaires coping with interviews, registered in audio files or annotated, according to the informant consensus. We interviewed 14 people, including 8 men and 6 women. The age of responders varies between 23 to 66 years old. The interviews were conducted followed by emic approach, considering how members perceive, structure, classify and articulate their world in their own terms (POSEY, 1986).

In ethnobotany data collect, we asked the informants to walk along the length of their properties for a correct survey of plants used by them, we annotated the popular names of the plants and separated them in four ethnocategory (food, shade, medicinal and ornamental), according to the informant's utility. In ethnozoology data collect, we investigated the mammals found in the region and the domestication and breeding of animals needed in sustenance. We also collect information about insects, mainly ants, this part of the work were exclusively directed to the ants and their relation with plants and humans, seen by riverine conception. Were also collected ants during interviews, with tweezers and placed in vials with alcohol $70 \%$ for further identification in laboratory.

\section{Results and discussion}

\subsection{The use of plants by local people}

Welisted 151 plant specimens considered important for residents, some of them were identified at the local by the researchers and others were collected, identified and deposited at herbarium of Universidade Federal de Mato Grosso, however, most of them are still in process of collect and identification, thus covering a bigger project. The plants were separated according to the informants on four ethnocategories of use: food (90 species), shade (26 species), medicinal (25 species) and ornamental (24 species). Food ethnocategory presents a larger number of plant species, $59.6 \%$ of total cited. This occur because riverine use plants to feed themselves and mainly as source of income by local commercialization of fruits, greens and vegetables coming from gardens and plantations in their properties, valuing and cultivating plants used in feeding.

Species used as food are also include in other ethnocategories, for example, mango trees Mangifera indica L, tamarind Tamarindus 
indica L and mulberry Morus nigra L were indicated in shade ethnocategory. Other plants were inserted both in medicinal and food ethnocategories as pomegranate Punica granatum and saffron Curcuma longa L, thus showing a multitude of use and maximizing resource. The multiplicity of ethnocategories was also observed by Moreira and GuarimNeto (2009) in a study conducted in the same state and biome of Rio Vermelho community, however, it shows a larger number $(86 \%$ of quoted amount) of plants used for medicinal purposes.

Most cited species are fruitful, which are easily grown and sold at fairs and stalls, such as banana Musa paradisiaca L $(100 \%$ of frequency) lemon Critus spp (100\%) and pineapple Ananas comosus L (83\%). After fruit species, are the vegetable crops as cucumbers Cucumis sativus L (33\%), okra Hibiscus esculentus L (33\%) and tomatoes Lycopersicon esculentum (Mill.) with $17 \%$ of citation

Figure 1: Frequency of plants included in the food ethnocategory in the studied properties

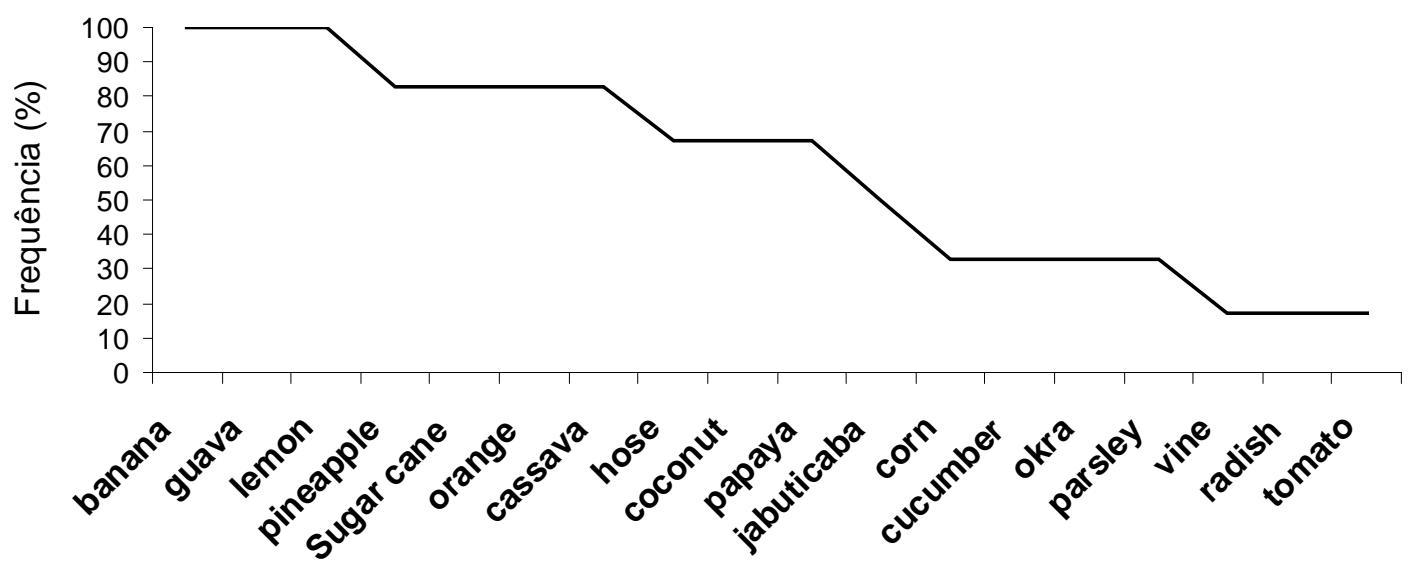

Results shown by Amaral and GuarimNeto (2008) present the fruit as the most used part of plants $(72 \%)$. In general, the parts of the plants used are the leaves, stems, fruit, seeds and roots. Vegetables are important sources of food, mainly through the consumption of leaves in salads, as the cases of lettuce Lactuca sativa, cabbage Brassica oleracea and chirory Cichoriu mendivia.

In contradiction of several ethnobotanic studies developed in Brazil as Moreira et al (2002), Pasa et al (2005), Torres et al (2009), Leitão et al (2009), Miranda and Hanazaki (2008), medicinal ethnocaterogy of use did not stand out among others, but kept a number of plants similar to shade and ornamental ethnocategories. What differed of this study to other ethnobiological studies in the same area can be easily explained, the Rio Vermelho Community is closer to the city than others communities, so, is not necessary to riverine cultivate medicinal plants, they are very accessible to pharmacies.
The area has been inhabited for only eleven years, so, most of the plants are remnants from native forest and others are brought from different places and ecosystems, particularly for those residents that came from south of Brazil. Guarim and Carniello (2008) said that these people usually come to buy cheap, unexplored and productive land. In a farmstead, inhabited by brazilian southerners, there are a wide variety of plants not endemic to cerrado biome, but they are still cultivated. As said by Amorozo (2008) these landscape units may play a key role in in situ conservation of germplams of the species and variety of useful plants which are not cultivated in conventional farming.

As said by Valadares and Pasa (2010) riverine from Rondonópolis city are responsible for supplying the region's horticulture and also commercialize their products in markets and stalls. Their vegetables are generally healthier and freer from chemicals, so, the valorization of this kind of community must be supported. 


\subsection{Ethnozoology approach and mamma- lian local composition}

Ancient connections between animals and human are seen in cultures throughout the world in multiple forms of interaction with the local fauna that form the core of Ethnozoology (ALVES; SOLTO, 2011). Montenegro and Marques (2001) said that cultural and biological diversity are partly responsible for the richness of names in fok taxonomy. It makes important to develop ethnobiological studies of denominations to the flora and fauna used by local human populations, concerning to understand the human/nature relations and cultural evolution.

The connection between the studied riverine population and animals are not extensive, but they showed to devote to animals part of their admiration (animals as part of the nature) and there are also families that use creations of animals or animal's products, just as they use in plants, as source of income and self consumption but to a less extent than plants.

Among the creations were found cattle, swine and poultry (chicken and duck), all in small numbers of specimens, due to the space of properties. Animal products are extracted, manufactured and marketed, such as cheese. The processing of cheese is done by women and the extraction of milk is role of men. Culturally we find the division of work by gender, a common practice in rural work of Mato Grosso state.

Among domesticated animals, were found dog (each property always keeping more than two dogs), cat and parrot. These animals are seen as part of playful in riverine's everyday and the dog gives protection to their properties against intruders and thieves, according to the riverine, they are very common in the region. Other animals, as parrot and macaw, can be caught and kept in captivity as pets although $100 \%$ of respondents said they do not practice hunting.

The practice of fishing was confirmed in $80 \%$ of male respondents and zero for female.

The main interest in fishing is having fun and because the meat is part of the family diet, being a rich source of protein. During all the process of fishing, men enjoy the nature and collect plants and fruits found in the riparian, using both to eat and planting.

Riverine were asked about wildlife seen on the region, especially vertebrates. In Table 01 is the relation of the mammalian local composition by the riverine's citation, scientific names were consulted according the mammal composition of a location in Mato Grosso state done by Rocha and Dalponte (2006).

Table 1: Mammal composition according riverine's citation. Scientific name according work done by Rocha and Dalponte (2006)

\begin{tabular}{ll} 
Taxa & Popular names \\
\hline Didelphimorphia & \\
Didelphidae & Possum \\
$\quad$ Didelphis albiventris (Lund, 1840) & \\
Xenarthra & \\
Dasypodidae & Six-banded armadillo \\
$\quad$ Euphractus sexcinctus (Linneaus, 1758) & \\
Myrmecophagidae & Ant bear \\
Myrmecophaga tridactyla (Linnaeus, 1758) & Anteater \\
Tamandua tridactyla (Linnaeus, 1758) & \\
Primates & \\
Atelidae & Howler monkey \\
Aloutta guariba (Humboldt, 1812) & \\
Cebidae & Capuchin monkey \\
Cebus nigritus (Goldfuss, 1809) & \\
Carnivora & \\
Felidae & Ocelot \\
Leopardus pardalis (Linnaeus, 1758) &
\end{tabular}




\begin{tabular}{ll} 
Taxa & Popular names \\
\hline Leopardus spp. & Wildcat \\
Puma concolor (Linnaeus, 1771) & Puma \\
Panthera onça (Linnaeus, 1758) & Jaguar \\
Mustelidae & \\
$\quad$ Pteronura brasiliensis (Gmelin, 1778) & Nutria \\
$\quad$ Eira barbara (Linnaeus, 1758) & Tayra \\
Artiodactyla & \\
$\quad$ Cervidae & \\
$\quad$ Mazama spp. & Deer \\
Rodentia & \\
Erethizontidae & \\
$\quad$ Sphiggurus spinosus (F. Cuvier, 1823) & Hedgehog \\
Cavidae & \\
$\quad$ Cavia aperea (Erxleben, 1777) & Prea \\
Dasyproctidae & \\
$\quad$ Dasyprocta azarae (Lichtenstein, 1823) & Agouti \\
Agoutidae & \\
Agouti paca (Linnaeus, 1766) & Paca
\end{tabular}

\subsection{Relationship between man, ant and plant}

Ants are dominant in most animal's terrestrial ecosystems representing $10 \%$ to $25 \%$ of total animal biomass. Thus, it was expected to record a greater number of ethnospecies cited by the residents, however, only four morphotypes were registered, differing from the work done by Costa-Neto and Rodrigues (2005), where was listed 42 ethnospecies of ants, including other arthropods in the ant ethnocategory.

We supposed the low number of ants cited is due to the low number of interviewed and because riverine shown to distinguish only species of ants malefic or benefic in right way to their vision and knowledge. The four morphotypes are: leafcutting ants (Atta spp and Acromyrmex spp), fire ant (Solenopsis spp) and army ants (Eciton burchelli). The first three they considered pests, by the damage aggravated by them in their crops. All popular names cited belong to correct taxonomy of Formicidae, except Odontomachus genus refereed once as Eciton burchellii, despite these ants show completely different in behaviors and morphology.

Atta and Acromyrmex - popularly known as leaf-cutting ants, these ants are major pests of reforestation in Brazil, both genders are responsible for significant losses of up to $30 \%$ impairment in the implementation phase of forests, accounting for $75 \%$ of the cost and time to control pests in reforestation (VILELA, 1986). All respondents were able to distinguish the two taxa of leafcutting ants, differing by the morphology and using correctly the popular names for the respective species. When asked about the type of plant that these ants usually attack, respondents said that leafcutting ants often attack plants with "thorns", especially Citrus spp, like orange Citrus aurantium L. and lemon Citrus limonum L., and also cassava Manihot esculenta L.; only two interviewee said Acromyrmex spp prefer roses Rosa spp. This information is correct, since the same plants were observed as preference for leafcutting ants by Hölldobler and Wilson (1980). Comparing to the work done by Costa-Neto and Rodrigues (2005), the terms used to ethnospecie Atta are the same, as "saúva", "formiga-de-asa", "formiga-de-mandioca", "tanajura", "formiga-cortadeira" and for Acromyrmex we registered "formigamineira".

Solenopsis - known popularly as fire ants and in portuguese we registered "lava-pé", species of this genus are fairly common in degraded areas by agricultural practices. Although studies have shown that Solenopsis are pests to Paricá tree Schizolobium amazonicum (LUNZ et al, 2009), this species is not recognized as a pest, but was the kind of ant that $100 \%$ of respondents said they had serious problems. 
According to local residents, Solenopsis attack cultivated plants, especially herbs and vegetables such as scarlet eggplant, lemongrass and rue. It is interesting to note the description of one informant about the behavior of Solenopsis ants, he said the ants attack mainly the leaves and after they contaminated the plants with a fungus, leading the plant to death, but it's necessary to sample studies to confirm this ethnocitation. Ants were collected in pointed plants and identified specimens were agreeing with interviewees' data, as Solenopsis sp.

Eciton burchellii - although $100 \%$ of respondents said they did not considered important any ant species, two interviewees described with good ecological aspects the habit of the ant Eciton burchellii, popularly known as army ants. This ant, according to the speech of the interviewees, brings clean soil due to their carnivorous and hunter habits, which kill and drag various types of invertebrates and even small vertebrates, however, what makes part of their diet are just larvae and pupae of other ants, wasps and other arthropods (RETTENMEYER et al, 2010). To interviewees, when ants carry with them animals such as cockroaches, spiders, scorpions, frogs, etc., can be beneficial to their property and their safety, since they consider them dangerous and unpleasant.

\section{Conclusion}

The use of plants and animals by this population is more related to a source of income than by self consumption. We can analyze it comparing the plants ethnocategories of use and the type of animals reared on fields. Looking to the self consumption, what favors the independence of the community by natural resources is the proximity to the city.

At the emic approach of the insects, especially ants, they described correctly its behavior and ecology, pointing out only those that directly affect them, not giving importance to other organisms important to the harmony of their community.

\section{Acknowledgements}

The authors thank all the residents from Rio Vermelho community for the permission given to conduct this research. The first author thanks CNPq to grant Pibic scholarship (20102011).

\section{References}

ALVES, R. R. N.; SOUTO, W. M. Ethnozoology in Brazil: current status and perspectives. Journal of Ethnobiology and Ethnomedicine, Londres, v. 7, n. 4, p. 7-22, 2011.

AMOROZO, M. C. M. Os Quintais - Funções, importância e futuro. In: GUARIM-NETO, G.; CARNIELLO, M. A. Quintais mato-grossenses: espaço de conservação e reprodução de saberes. Cáceres: Unemat, 2008. p. 15-27.

CLEMENT, C. R. Introduction to botanical resources. In: POSEY, D. A.; OVERAL, W. L.; CLEMENT, C. R.; PLOTKIN, M. J.; ELISABETSKY, E.; MOTA, C. N; BARROS, J. F. P. Ethnobiology: implications and applications. Belém: Museu Paraense Emílio Goeldi, 1990. p. 245-247.

COSTA-NETO, E. M.; RODRIGUES, R. M. F. R. As formigas (Insecta: Hymenoptera) na concepção dos moradores de Pedra Branca, Santa Terezinha, Estado da Bahia, Brasil. Boletín Sociedad Entomológica Aragonesa, Zaragoza, n. 37, p. 353-364, 2005.

GUARIM-NETO, G.; CARNIELLO, M. A. Quintais mato-grossenses: espaço de conservação e reprodução de saberes. Cáceres: Unemat, 2008. p. 129-155.

HÖLLDOBLER, B.; WILSON, E. O. The leafcutting ants. In: HÖLLDOBLER, B.; WILSON, E. O. The Ants. Massachusetts: Belknap; Harvard, 1990. 732 p.

LUNZ, A. Met al. Danos de Solenopsis saevissima F Smith (Hymenoptera: Formicidae) em Paricá, Schizolobium amazonicum. Neotropical Entomology, Londrina, v. 32, n. 2, p. 285-288, 2009.

MIRANDA, T. M; HAZANAKI, N. Conhecimento e uso de recursos vegetais de restinga por comunidades das ilhas do Cardoso (SP) e de Santa Catarina (SC). Acta Botânica Brasilica, Feira de Santana, v. 22, n. 1, p. 203-215, 2008.

MONTENEGRO, S. C. S.; MARQUES, J. G. Contexto cultural, ecológico e econômico da produção e ocupação dos espaços de pesca pelos pescadores de pitu (Macrobrachium carcinus) em um trecho do Baixo São Francisco, Alagoas-Brasil. Interciência, Venezuela, v. 26, n. 11, p. 535-540, 2001.

MOREIRA, D. L., GUARIM NETO, G. Uso dos múltiplos de plantas do cerrado: um estudo etnobotânico na comunidade Sítio Pindura, Rosário Oeste, Mato Grosso, Brasil. Polibotànica, Mexico, v. 24, n. 27, p 159-190. 2009.

MOREIRA, R. C. T.; COSTA, L. C. D. B.; COSTA, R. C. S.; ROCHA, E. A. Abordagem etnobotânica acerca do uso de plantas medicinais na Vila Cachoeira, Ilhéus, Bahia, Brasil. Acta Farmacéutica Bonaerense, v. 21, p. 205-211, 2002.

PASA, M. C.; SOARES, J. S.; GUARIM-NETO, G. Estudo etnobotânico na comunidade de Conceição-Açu (alto da bacia do rio Aricá-Açu, MT, Brasil). Acta Botânica Brasília, Feira de Santana, v. 19, n. 2, p. 195-207, 2005.

RETTENMEYER, W.; RETTENMEYR, M. E.; BERGHOFF, S. M. The largest animal association centered on one species: the army ant Eciton burchellii and its more than 300 associates. Insectes Sociaux, v. 38, n. 3, p. 281-292, 2010 
SETTE, D. M.; TARIFA, J. R. Clima e ambiente urbano tropical: o caso de Rondonópolis-MT. Intergeo, Rondonópolis, v. 1, p. 7-34, 2001.

TORRES, D. F.; OLIVEIRA, E. S.; ALVES, R. R. N.; VASCONCELLOS, A. Etnobotânia e Etnozoologia em unidades de conservação: uso da biodiversidade na APA de Genipabu, Rio Grande do Norte, Brasil. Interciência, v. 34, n. 9, p. 623-629, 2009.
VALADARES, L. C. A.; PASA, M. C. Pest control methods used by riverine from Rio Vermelho community, south of Mato Grosso state, Brazil. Biodiversidade, Rondonópolis, v. 9, n. 1, p. 4-14, 2010.

VILELA, E. V. Status of leaf-cutting ant control in Forest plantations in Brazil. In: LOFGREN, C. S.; VANDER MEER, R. K. Fire ants and leaf-cuttings ants: biology and management. Boulder: Westview, 1986. p. 399-408. 